\title{
Colonial grievances, justice and reconciliation in the Pacific
}

Toon van Meijl and Michael Goldsmith

\section{Q OpenEdition \\ 1 Journals}

\section{Electronic version}

URL: http://journals.openedition.org/jso/908

DOI: $10.4000 /$ jso. 908

ISSN: $1760-7256$

\section{Publisher}

Société des océanistes

\section{Printed version}

Date of publication: 1 December 2007

Number of pages: 201-207

ISBN: 978-2-85430-010-9

ISSN: 0300-953x

\section{Electronic reference}

Toon van Meijl and Michael Goldsmith, "Colonial grievances, justice and reconciliation in the Pacific », Journal de la Société des Océanistes [Online], 125 | Année 2007-2, Online since 01 December 2010, connection on 20 April 2019. URL : http://journals.openedition.org/jso/908 ; DOI : 10.4000/jso.908

(C) Tous droits réservés 


\section{Colonial grievances, justice and reconciliation in the Pacific ${ }^{1}$}

by

Toon van MEIJL* and Michael GOLDSMITH**

The paradox of the decolonization process in the Pacific is that colonial grievances seem to have proliferated in the recent past. Indeed, anticolonial sentiments often seem to be more directly spurred by the process of decolonization than by the practices of colonial regimes revelling in earlier peaks of power. This workshop was concerned with the question how to address this contemporary form of counter-hegemonic resistance in the Pacific. The aim of the session was, first, to examine the similarities and differences in colonial grievances throughout the Pacific and, second, to discuss the various strategies that may be developed to establish justice and to realize reconciliation.

Colonial grievances are expressed in a variety of different ethno-historical conditions. Indigenous minorities in settler states, notably in New Zealand, Australia and Hawai'i, are demanding the restoration of sovereignty and the return of properties that were dispossessed in the colonial past. Postcolonial nation-states that have obtained independence relatively recently, particularly small island states in Polynesia, but also Papua New Guinea, for example, continue to remind their former colonizers of their responsibility to redress economic difficulties that are blamed on the history of colonization. The ongoing debate about the international exploitation of natural resources in the Pacific, especially in Melanesia, although not restricted to colonialism and its immediate consequences, is deeply rooted in its history.

At the same time, requests for the repossession, if not repatriation, of cultural heritage under trust of former colonizers, e.g. in collections of ethnographic museums, are emerging from the uneasy relationship between colonizers and colonized, not only in the Pacific, but throughout the world. Colonialism has also left a whole range of other legacies that are in need of a permanent solution, such as the different forms of ethnic tension in Fiji, the Solomon Islands, New Zealand, Australia and Hawai'i.

Political discussions in these divergent circumstances generally revolve around the issue of who is responsible for the harm that colonialism inflicted and the related issue of who was harmed. These lead, in turn, to the further questions of how the perpetrators of harm are identified, how deserving cases of justice and reconciliation are constructed, and how the relevant discourses of responsibility respond to historical, political and cultural change. The organizers invited casestudies on these questions from all Pacific societies. For various reasons, not all of the resulting contributions are able to be discussed here but we are grateful to the participants for a lively session. In the following section we discuss those papers that we propose to bring to publication.

1. Presentation of the first session of the $6^{\text {th }}$ Conference of the European Society for Oceanists, at Marseille (July 8-10 2005).

* University of Nijmegen, The Netherlands, T.vanMeijl@ru.nl

** University of Waikato, Hamilton, New Zealand, mikegold@waikato.ac.nz 


\section{Seven case-studies}

In his paper entitled «The colonial and postcolonial roots of ethnonationalism in Tuvalu», Michael Goldsmith from the University of Waikato in New Zealand began by criticizing the tendency of some commentators to overstate a distinction between sovereign Pacific Island countries that gained independence easily and those that had to struggle for such an outcome. Even the history of the small Pacific microstate of Tuvalu, granted independence in 1978 (with the apparent blessings of Britain but in fact with a degree of reluctance) after some six decades of ostensibly benign rule, can be couched in terms of grievance and redress. This despite the fact that Tuvaluans were the recipients of a kind of positive discrimination on the part of the authorities running the Gilbert and Ellice Islands Colony (Tuvalu being formed out of the Ellice Islands at the time of the break-up of the Colony in 1975). Though there is no deep animosity towards Britain in Tuvalu, colonialism did create problems that eventually came back to haunt the players concerned.

Goldsmith's paper investigated the issue of colonial and post-colonial grievances in the construction of a sense of ethno-nationalism in Tuvalu. By comparison with some other countries, this sentiment is not passionately held, but it is real and its roots are understandable. They have more to do with the way in which the colonial power treated Tuvalu during decolonization than with the prior impact of the colonial regime per se. The paper briefly explored the historical background before addressing the grievances that arose around the time of independence and their consequences (Macdonald, 1975). The paper argued that the establishment of the Tuvalu Trust Fund in 1987 is best understood in terms of a convergence between the Tuvaluan sense of grievance and the colonisers' recognition that Tuvaluans had been treated unjustly in the lead-up to independence.

More recently, Tuvalu has become the international symbol of a global grievance - the threat to maritime microstates and their national sovereignty posed by the possibilities of climate change, global warming, and sea-level rise (Chambers and Chambers, 2007; Connell, 2003; 2004; Farbotko, 2005; Goldsmith, 2005). Even here, Tuvalu's environmentalist stance has roots in earlier episodes of colonial history. The resulting issues of justice, agency and responsibility are complex and double-edged.

In her contribution "Taukei (indigenous rights) and the new face of western hegemony in
Fiji», Marilyn E. Lashley from Howard University in the USA focused on the emerging calls for indigenous rights in Fiji since the beginning of a series of coups d'état in May 1987. Lashley examined what she posits as the central causes of political unrest in the Republic of Fiji. To this end, she defined the concepts of sovereignty and 'indigenousness', and presented a brief overview of Fiji's political and economic history, the country's processes of political mobilization, and its evolution as a (nominally) democratic state. Lashley's paper also addressed the vexed question surrounding the nature of political rule in Fiji, who actually rules and who ought to rule. Lashley advanced an interpretation of why and how indigenous (ethnic) Fijians remain marginal and impoverished within their own land despite their orderly transition to independence and despite having secured control over the political apparatus of the Fijian nation state. The paper also discussed the new realities confronted by Fijians and Indo-Fijians that frustrate efforts of both groups to achieve social justice, ethnic harmony, political stability and international legitimacy.

This was probably the most contentious paper of the whole session, if its initial reception is a guide. Several experts on Fiji (some of them citizens) were in the audience and expressed concerns over the interpretations put forward. For example, using the term 'Indian' for the category of people whose ancestry derives wholly or predominantly from that background is resisted by many who belong to the category. They generally prefer the term 'Indo-Fijian', which Lashley controversially reserved for those of mixed heritage. These designations are highly problematic, not least because they deny some citizens of Fiji the right to ethnic self-ascription - a right which has become sacred writ since the groundbreaking rethinking of ethnic boundaries by Fredrik Barth (1969).

The level of disagreement on display was no real surprise, as the 'race' issue in Fiji has always been as much a political minefield as an arena of scholarly debate (Cottrell and Ghai, 2007; Ratuva, 2003). Evenhandedness is a difficult balance to strike in such circumstances. Lashley circumvented the problem by firmly attaching her colours to the ethnic Fijian nationalist masthead. (Nor is she alone in this regard as political polarization in recent years has led some previously liberal multiculturalists towards a more nationalist stance - see Carens, 2000; Vakatale, 2000.)

For this and other reasons, the paper had clear political links to the papers by Margaret Mutu 
and Ann Sullivan, each of which took a line that was strongly critical of state policies and wider societal racism in New Zealand.

Lashley's main political-economy conclusion, however, that Indians are economically much better off than Fijians, arguably downplays the role of ethnic Fijian elites in exploitation as well as the genuine poverty of Indo-Fijians at the bottom of the heap (Kumar and Prasad, 2004; Trnka, 2005, 2006). It also fails to take into account Fijian subsistence opportunities and ambivalence over «the way of money» (as expressed in the writings of Christina Toren [1989] and Matthew Tomlinson [2004], for example). Despite these shortcomings, the convenors felt the paper had its place as a densely argued, if provocative, take on the Fijian situation.

Daniel Moretti, at the time a $\mathrm{PhD}$ student from Brunel University in the UK, presented a fascinating paper on mythological accounts of colonial history and requests for reparation, entitled "Gold, tadpoles, and Jesus in the manger: reflecting on cosmogony, colonial extraction and restitution with the Hamtai-Anga of Mount Kaindi, Morobe Province, Papua New Guinea». Following an established approach within the regional anthropology of "cargo cults» and of resource development (Biersack, 1999, 2006; Clark, 1993, 2000; Golub, 2006; Hirsch, 2001; Jorgensen, 2006; Kirsch, 2007), this paper used a local cosmogony to investigate how a PNG mining community views the colonial past and what forms of redressive action it demands from the former colonial masters (see also Moretti, 2006).

Moretti argued that contemporary PNG discourses about colonialism cannot be understood simply in terms of past interactions between colonisers and colonised, but should also be viewed as strategic responses to postindependence power relations between different ethno-linguistic groups and between local communities and the state. Only in this light can we appreciate why the Hamtai-Anga of Kaindi do not follow demands for the restitution of misappropriated properties with calls for the severance of all relations with the former colonial masters, but rather anticipate that the latter return as resource developers and as guarantors of their independence from other communities and the National Government.

Those who heard and subsequently read this presentation could not help but be struck by the richness of Moretti's account, full of ethnographic and historical information and complemented by genuine theoretical insight. It seems a shame to abridge the complex mythical narrati- ves that intertwine with his archival research to give the argument its empirical force but the exigencies of publishing mean that future readers will almost certainly not have access to the whole story.

John Morton, working at La Trobe University in Australia, presented a thoughtful paper on the stolen generation in Australia, entitled «Race, reciprocity and reconciliation: Australian Aboriginal kinship lessons for restorative justice». According to Morton, in recent decades, the vexed question of the legitimacy of Australia's assimilation policies has largely focused on the so-called 'stolen generations' - Aboriginal children (largely of mixed descent) removed from their natal families to be raised in institutions or foster homes (Beresford and Omaji, 1998; Creed, 2001; Glowczewski, 2005; Krieken, 1999). In this paper, he examined assimilationist child removal policies in terms of their intentions to «breed out the coloury from the Australian population as a whole, as part of the state's dedication to «White Australia». More specifically, he investigated the nature of the dualism inherent in relationships between «black» and «white» Australia and compared it to prescribed forms of dualism inherent in classical systems of Aboriginal kinship and marriage (cf. Morton, 1998). Drawing on Marcel Mauss's classic study The Gift (1967), Morton suggested that certain moral conclusions can be drawn from this comparison - conclusions that have been both acknowledged and denied in political terms in Australia, but which cannot be challenged on ethical grounds (Morton, 2003).

This was another empirically rich paper, and probably the most theoretically ambitious of all those presented in the session. The idea that notions of kinship and reciprocity need to be brought to bear on the 'stolen generations' has great anthropological resonance with similar Pacific cases imbricating race and 'sexual commerce', including some that Morton himself did not cite, such as Sahlins' $(1981,1995)$ or Tcherkézoff's (2004a, 2004b) writings on Captain Cook and other explorers. Interestingly, Morton alluded to these comparative potentials by means of a reference to Australian Aboriginal Cook narratives as examples of «the unfulfilled promise of reciprocity». Contrary to certain anthropological shibboleths, he argued, biologisms such as 'race' do exist and have force in this context.

Some readers of this paper in its eventual published form may be disconcerted by what appears to be its resort to a slightly distant and abstract statement on matters that are hard for 
those opposed to racism to disentangle from a stance of moral outrage - but in the end that was one of its strengths. Big questions remain, however. For example, once the politics of recognition have been sorted out, won't there be an even bigger conflict in Australia over the politics and justice of redistribution? In this light, the paper raised fascinating and disturbing parallels with the papers on New Zealand by Mutu, Sullivan and Van Meijl.

In a paper entitled «Recovering the crown's ill-gotten gains», Margaret Mutu from the University of Auckland in New Zealand discussed the process in which Maori and the New Zealand government are negotiating the settlement of grievances about the dispossession of their land in the nineteenth century and other associated breaches of the Treaty of Waitangi. This Treaty was signed in 1840 between a number of Maori chiefs and the governor representing the British Crown in New Zealand, and it guaranteed Maori ownership of their lands and other natural resources in exchange for the cession of governance (Kawharu 1989, Orange 1987). In the course of history, however, the Treaty was violated causing Maori to become a disadvantaged minority in their own land. Since the mid1980s, however, the Treaty has gradually become recognized which also makes it possible for Maori to submit claims to the Waitangi Tribunal about breaches of the Treaty. Some 1200 claims have been lodged by Maori, but fewer than 20 have been settled. Mutu discussed the difficulties experienced by Maori in the claims settlement process, drawing on case-studies of several Maori tribes involved in direct negotiations with the Crown.

Mutu outlined the legal and political context in which negotiations are currently taking place between Maori and government, after which she continued to provide a detailed account of the historical claims by a number of tribal groupings in the far North of the North Island of New Zealand. This account was impressive not only because it illustrated what the situation would be for Ngaati Kahu had the Treaty not been violated, which the author deduced by systematic comparison with non-Maori in the same area, but also because it offered a detailed overview of the history of the claim and the negotiations between Ngaati Kaahu and the New Zealand government, which have been going on since 1986. Since not much progress has been made over the past two decades, it is not surprising that Maori patience is being tested in this case, all the more since the Crown has since passed legislation regarding the foreshore and the seabed which most Maori consider as yet another confiscation of their territories (Erueti and Charters 2007).

The question about the ownership of New Zealand's foreshore and seabed was the subject of the contribution by Ann Sullivan, also from the University of Auckland, entitled «Justice, indigenous rights and the public good: Who owns the foreshore and the seabed?» The main issues in the controversy around the foreshore and the seabed revolve around the question whether land under water has remained Maori land protected by the doctrine of aboriginal title (Ruru, 2004). The foreshore is the area between the high water mark and the low water mark or the 'wet' part of the beach that is covered by the ebb and flow of the tide. The seabed is the area from the low water mark to the outer limits of the territorial sea, 12 nautical miles from shore. The question regarding the proprietary status of the foreshore and the seabed emerged among several tribes on the South Island, which were frustrated in their attempts to establish marine farms on land that they believed was customarily theirs. They submitted their case to the Maori Land Court, but a legal dispute emerged about the question whether aboriginal title can exist in regard to the foreshore and the seabed, and also whether it can exist to the extent of exclusive ownership. Six years of litigation about these questions culminated in a verdict of the Court of Appeal, announced on 19 June 2003, that avoided declaring that such land exists in New Zealand, but it did rule that Maori should be offered the opportunity to proceed with their application to the Maori Land Court.

Since the ruling of the Court of Appeal did not foreclose the possibility of Maori being able to effectively obtain private ownership of the foreshore and the seabed, the New Zealand government immediately responded by proclaiming its intention to enshrine Crown ownership of the foreshore and the seabed in law. The government justified its plan by arguing that it had a responsibility to regulate the rights and interests of all New Zealand citizens, which included guaranteeing public access to the country's beaches for everyone. This move of the government, however, has angered Maori throughout the country since they are no longer allowed to go to court to determine whether the foreshore and seabed are customary property and therefore they argue that the new law effectively dispossesses them of existing property rights ( $c f$. Waitangi Tribunal 2004). Maori response has been vocal and visible, and although it has been restrained and peaceful to date, ethnic 
tension has heightened and a polarized nation has emerged in New Zealand. Sullivan discussed the case of the controversy around the foreshore and the seabed in New Zealand in terms of the broader issue of justice and reparation by showing how the current political climate is changing the reparation discourse of the past twenty years (Belgrave, Kawharu and Williams, 2005).

In a more theoretical contribution about the settlement process in New Zealand, Toon van Meijl aimed at analysing why the resolution of Maori claims, which initially appeared hopeful for the future, seems to create new problems in Maori society. In his view, the settlement process in New Zealand is hampered for two reasons. First, the government negotiates settlements only with tribal organisations, whereas $80 \%$ of the Maori population is currently living in urban environments in which tribal connections have lost a great deal of meaning. Hence, too, the central position of tribes in the settlement process is contested by pan-tribal groupings in urban environments. Second, local sub-tribes are sometime challenging the centralised structures of governance implemented by tribes that have signed a compensation settlement with the government. Both issues illustrate that the sociopolitical organisation of Maori society has changed radically since the nineteenth century, which raises the question regarding the representation for descendants of the Maori who were originally dispossessed. This question is preceded by the more fundamental question about the nature of property rights in the nineteenth century. Who used to own the land and other resources: extended families, sub-tribes, tribes, or supertribes?

In order to disentangle the complex issues underlying the difficulties of the settlement process in Maori society, Van Meijl used a historical and legal anthropological framework (Von Benda-Beckmann, F., K. von Benda-Beckmann and Wiber, 2006; Humphrey and Verdery, 2004). $\mathrm{He}$ analysed the evolution of Maori forms of socio-political organisation under the impact of colonialism. In addition, he tried to unpack the complexities and manifold variations of property at different layers of socio-political organisation in Maori society, e.g. tribes (iwi), subtribes (hapuu) and extended families (whaanau), in different periods of history. His conclusion was that disputes in Maori society about the management of returned resources and compensation funds are caused by a clash between different property regimes, one characterized by intersecting rights and without a clear concept of ownership, and the other characterized by a bounded conception of ownership that was introduced into Maori society by the government, in cooperation with a number of ambitious Maori chiefs (Ballara, 1998). The New Zealand government is only willing to negotiate the settlement of claims with registered tribes and requires these to conform to certain rules of governance, as a result of which it can be argued that the radical restructuring of the traditional socio-political organisation in Maori society has been sparked off by conditions stipulated by the government to Maori in order to become eligible for the return of Maori resources to Maori custody and control, or should we say 'ownership'? Did the government perhaps also introduce western concepts of ownership into a society that originally didn't recognize ownership in the strict sense of the term, only a flexible range of rights in relation to resources? It remains to be seen, however, whether recent changes of Maori property categories may in due course also change Maori property relations in practice.

In sum, these seven papers exemplify the legacy of colonialism in contemporary Pacific societies and illustrate how difficult it is to resolve complex problems that result directly from the colonial history but that are currently being tackled under circumstances that have drastically changed over time and are therefore radically different from the past. For that reason, too, it is inherently difficult to establish justice since the settlement of colonial grievances may in turn create new problems, while the perception of these problems will also continue to change in the foreseeable future. In countries with a colonial history, too, reconciliation will perforce remain a goal, instead of a stable settlement, that former colonizers and colonized will have to continue to negotiate.

\section{BIBLIOGRAPHY}

Ballara Angela, 1998. Iwi: The Dynamics of Maaori Tribal Organisation from c.1769 to c.1945, Wellington, Victoria University Press.

BARTH Fredrik (ed.), 1969. Ethnic Groups and Boundaries: The Social Organization of Cultural Difference, Bergen, Universitetsforlaget/London, Allen and Unwin.

Belgrave Michael, Merata Kawharu and David Williams (eds.), 2005. Waitangi Revisited: Perspectives on the Treaty of Waitangi, Melbourne, Oxford University Press.

Benda-Beckmann Franz von, Keebet von BendABeckmann and Melanie Wiber, 2006. The Proper- 
ties of Property, in F.v. Benda-Beckmann, K.v. Benda-Beckmann and M. Wiber (eds.), Changing Properties of Property, New York/Oxford, Berghahn, pp. 1-39.

BERESFORd Quentin and Paul OMajI, 1998. Our State of Mind: Racial Planning and the Stolen Generations, Fremantle WA, Fremantle Arts Centre Press.

BiERsaCK Aletta, 1999. The Mount Kare Python and His Gold: Totemism and Ecology in the Papua New Guinea Highlands, American Anthropologist 101 (1), pp. 68-87.

_, 2006. Red River, Green War: The Politics of Place along the Porgera River, in Aletta Biersack and James B. Greenberg (eds), Reimagining Political Ecology, Durham NC, Duke University Press.

Carens Joseph H., 2000. Culture, Citizenship and Community: A Contextual Exploration of Justice as Evenhandedness, Oxford, Oxford University Press.

Chambers Anne and Keith, 2007. Five Takes on Climate and Cultural Change in Tuvalu, Contemporary Pacific 19 (1), pp. 294-306.

Clark Jeffrey, 1993. Gold, Sex, and Pollution: Male Illness and Myth at Mt. Kare, Papua New Guinea, American Ethnologist 20 (4), pp. 742-57.

_, 2000. Steel to Stone: A Chronicle of Colonialism in the Southern Highlands of Papua New Guinea, Oxford, Oxford University Press.

ConNell John, 2003. Losing Ground? Tuvalu, the Greenhouse Effect and the Garbage Can, Asia Pacific Viewpoint 44 (2), pp. 89-107.

—, 2004. Environmental Change, Economic Develop ment, and Emigration in Tuvalu, in Victoria S. Lockwood (ed.), Globalization and Culture Change in the Pacific Islands, Upper Saddle River NJ, Pearson Education.

Cottrell Jill and Yash GHaI, 2007. Constitutionalising Affirmative Action in the Fiji Islands, International Journal of Human Rights 11 (1), pp. 227-257.

CreEd Barbara, 2001. Breeding Out the Black: Jedda and the Stolen Generations in Australia, in Barbara Creed and Jeanette Hoorn (eds), Body Trade: Captivity, Cannibalism and Colonialism in the Pacific, New York, Routledge/Dunedin, University of Otago Press.

Erueti Andrew and Claire Charters (eds), 2007. Maori Property in the Seabed and Foreshore: The Last Frontier, Wellington, Victoria University Press.

Farbotko Carol, 2005. Tuvalu and Climate Change: Constructions of Environmental Displacement in the Sydney Morning Herald, Geografiska Annaler 87B, pp. 279-293.

Glowczewski Barbara, 2005. In Australia, it's 'Aboriginal' with a Capital 'A': Aboriginality, Politics and Identity, in Serge Tcherkézoff and Françoise Douaire-Marsaudon (eds), The Changing South Pacific: Identities and Transformations, Canberra, Pandanus Books.
Goldsmith Michael, 2005. Theories of Governance and Pacific Microstates: The Cautionary Tale of Tuvalu, Asia Pacific Viewpoint 46 (2), pp. 105-114.

Golub Alex, 2006. Who is the 'Original Affluent Society’? Ipili 'Predatory Expansion' and the Porgera Gold Mine, Papua New Guinea, Contemporary Pacific 18 (2), pp. 265-292.

Hirsch Eric, 2001. New Boundaries of Influence in Highland Papua: 'Culture', Mining and Ritual Conversion, Oceania 71 (4), pp. 298-312.

Humphrey Caroline and Katherine Verdery, 2004. Introduction: Raising Questions About Property, in K. Verdery and C. Humphrey (eds.), Property in Question: Value Transformation in the Global Economy, Oxford/New York, Berg, pp. 1-25.

JoRGENSEN Dan, 2006. Hinterland History: The Ok Tedi Mine and its Cultural Consequences in Telefolmin, Contemporary Pacific 18 (2), pp. 233-263.

KaWharu I.H. (ed.), 1989. Waitangi; Maaori \& Paakehaa Perspectives of the Treaty of Waitangi, Auckland, Oxford University Press.

KIRSCH Stuart, 2007. Indigenous Movements and the Risks of Counterglobalization: Tracking the Campaign Against Papua New Guinea's Ok Tedi Mine, American Ethnologist 34 (2), pp. 303-321.

KRIEKEN Robert van, 1999. The Barbarism of Civilization: Cultural Genocide and the 'Stolen Generations'. British Journal of Sociology 50 (2), pp. 297315.

Kumar Sunil and Biman Prasad, 2004. Politics of Race and Poverty in Fiji: A Case of Indo-Fijian Community, International Journal of Social Economics 31 (5/6), pp. 469-486.

Macdonald Barrie, 1975. Secession in Defence of Identity: The Making of Tuvalu, Pacific Viewpoint 16 (1), pp. 26-44.

Mauss Marcel, 1967. The Gift: Forms and Functions of Exchange in Archaic Societies, New York, Norton.

Moretri Daniele, 2006. The Gender of the Gold: An Ethnographic and Historical Account of Women's Involvement in Artisanal and Small-Scale Mining in Mount Kaindi, Papua New Guinea, Oceania 76 (2), pp. 133-149.

Morton John, 1998. Essentially Black, Essentially Australian, Essentially Opposed: Australian Anthropology and Its Uses of Aboriginal Identity, in Jürg Wassmann (ed. ), Pacific Answers to Western Hegemony: Cultural Practices of Identity Construction, Oxford, Berg.

_, 2003. Abortive Redemption? Apology, History and Subjectivity in Australian Reconciliation, in Toon van Meijl and Michael Goldsmith (eds), Postcolonial Dilemmas: Reappraising Justice and Identity in New Zealand and Australia, Journal of the Polynesian Society 112 (3) Special Issue, pp. 238259.

Orange Claudia, 1987. The Treaty of Waitangi, Wellington, Allen \& Unwin/Port Nicholson. 
RatuVA Steven, 2003. Le paradoxe du multiculturalisme : gestion des différences dans l'État syncrétique de Fidji, in Paul de Deckker et Jean-Yves Faberon (eds), L'État pluriculturel et les droits aux différences, Bruxelles, Bruylant.

RuRU Jacinta, 2004. A Politically Fuelled Tsunami: The Foreshore/Seabed Controversy in Aotearoa me te Wai Pounamu/New Zealand, The Journal of the Polynesian Society 113 (1), pp. 57-72.

SAHLins Marshall, 1981. Historical Metaphors and Mythical Realities, Ann Arbor, University of Michigan Press.

—, 1995. How "Natives" Think: About Captain Cook, For Example, Chicago, University of Chicago Press.

TCHERKÉzofF Serge, 2004a. Tahiti 1768. Jeunes filles en pleurs : la face cachée des premiers contacts et la naissance du mythe occidental, Papeete, Au Vent des Iles.

—, 2004b. 'First Contacts' in Polynesia: The Samoan Case (1722-1848). Western Misunderstandings about Sexuality and Divinity, Canberra, Journal of Pacific History/ Christchurch, Macmillan Brown Centre for Pacific Studies.

Tomlinson Matt, 2004. Perpetual Lament: KavaDrinking, Christianity and Sensations of Historical Decline in Fiji, Journal of the Royal Anthropological Institute 10 (3), pp. 653-673.
Toren Christina, 1989. Drinking Cash: The Purification of Money Through Ceremonial Exchange in Fiji, in Jonathan Parry and Maurice Bloch (eds), Money and the Morality of Exchange, Cambridge, Cambridge University Press.

TrNKA Susanna, 2005. Land, Life and Labour: IndoFijian Claims to Citizenship in a Changing Fiji, in Elfriede Hermann and Wolfgang Kempf (eds), Oceania 75 (4) Special Issue, pp. 354-367.

_ 2006. Between Victims and Assailants, Victims and Friends: Sociality and the Imagination in IndoFijian Narratives of Rural Violence during the May 2000 Fiji Coup, in Andrew Strathern, Pamela J. Stewart and Neil Whitehead (eds), Terror and Violence: Imagination and the Unimaginable, London, Pluto Press.

VaKatale Taufa, 2000a. Multiculturalism vs Indigenous Cultural Rights, in Margaret Wilson and Paul Hunt (eds), Culture, Rights, and Cultural Rights: Perspectives from the South Pacific, Wellington, Huia Press.

Waitangi Tribunal, 2004. Report on the Crown's Foreshore and Seabed Policy, Wellington, Waitangi Tribunal, WAI 1071. 